\title{
Evaluation of a cross contamination model describing transfer of salmonella spp. and listeria monocytogenes during grinding of pork and beef
}

Møller, Cleide Oliveira de Almeida; de Anderson, S. Sant' Ana; Nauta, Maarten; Aabo, Søren; Hansen, Tina Beck

Publication date:

2015

Document Version

Publisher's PDF, also known as Version of record

Link back to DTU Orbit

Citation (APA):

Møller, C. O. D. A., de Anderson, S. S. A., Nauta, M., Aabo, S., \& Hansen, T. B. (2015). Evaluation of a cross contamination model describing transfer of salmonella spp. and listeria monocytogenes during grinding of pork and beef. Poster session presented at The Danish Microbiological Society Annual Congress 2015, Copenhagen, Denmark.

\section{General rights}

Copyright and moral rights for the publications made accessible in the public portal are retained by the authors and/or other copyright owners and it is a condition of accessing publications that users recognise and abide by the legal requirements associated with these rights.

- Users may download and print one copy of any publication from the public portal for the purpose of private study or research.

- You may not further distribute the material or use it for any profit-making activity or commercial gain

- You may freely distribute the URL identifying the publication in the public portal 
Evaluation of a cross contamination model describing transfer of Salmonella spp. and Listeria monocytogenes during grinding of pork and beef

Cleide O. de A. Møller1 ${ }^{1}$, Anderson de S. Sant'Ana',3 Maarten J. Nauta,

Søren Aabo ${ }^{1}$ and Tina B. Hansen ${ }^{1}$

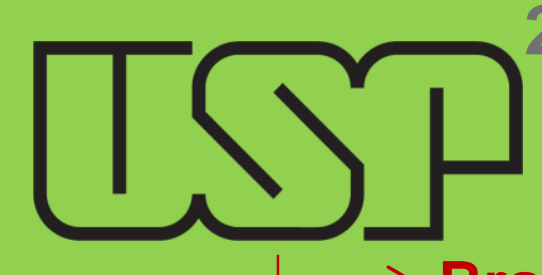

UNICAMP

Can a promising cross contamination model be successfully applied to any condition of meat grinding? To answer this question we performed different challenge tests and developed a set of evaluation approaches.

The cross contamination model (Møller et al. 2012) was evaluated to investigate its capability of describing transfer of Salmonella spp. and $L$. monocytogenes during grinding of pork and beef of varying sizes $(50-324 \mathrm{~g})$ and numbers of pieces to be ground $(10-100)$, in two grinder systems.

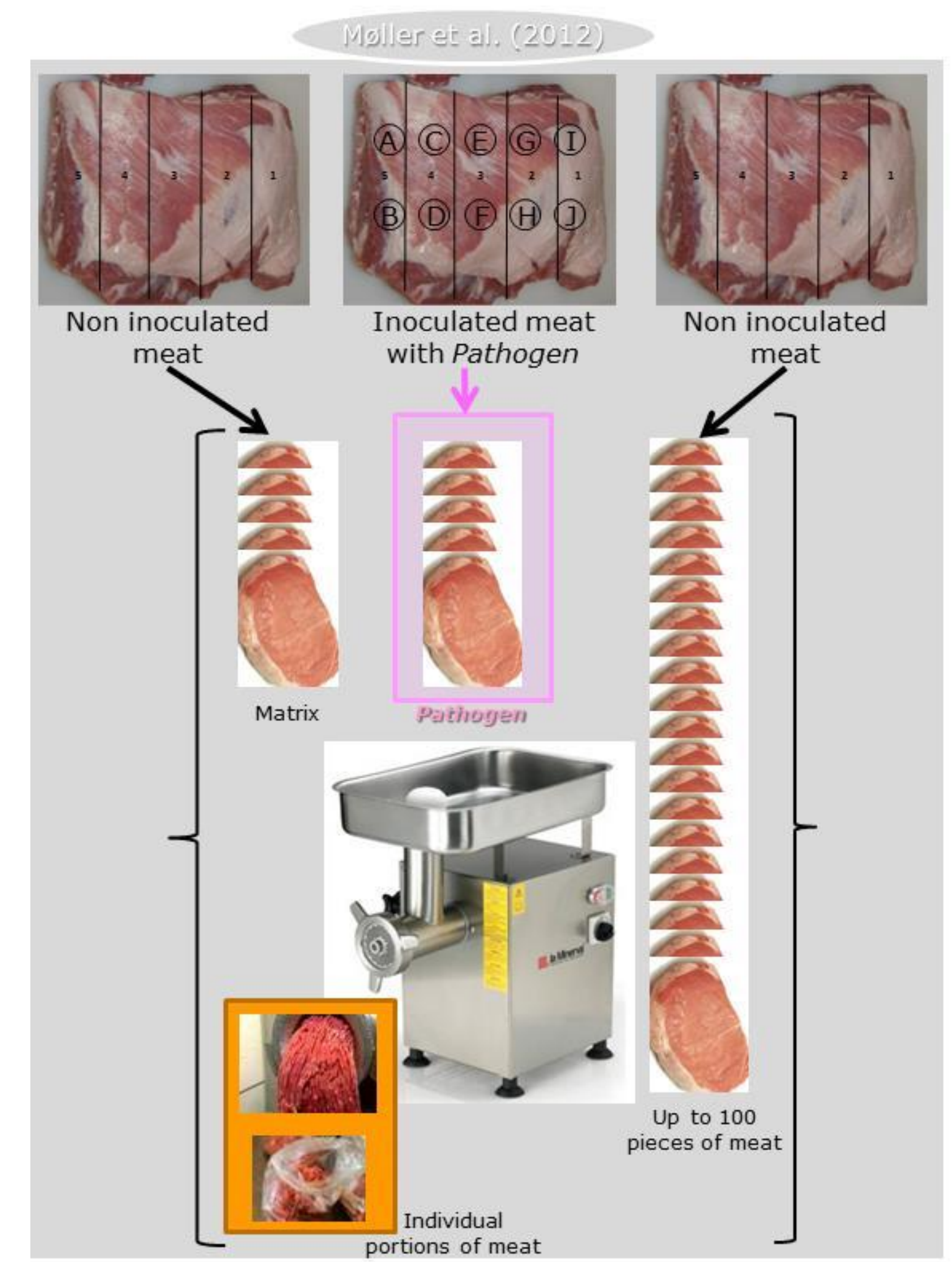

Data from 19 trials were collected. Three different evaluation approaches were applied:

i) ASZ - an Acceptable Simulation Zone method which compared observed transfer with simulations using the proposed model

ii) QMRA - each trial was fitted to equation 1 and its respective paramete estimates were integrated in a Quantitative Microbiological Risk Assessment model (Møller et al. 2015) to compare risk estimates

iii) TTP - the Total Transfer Potential was calculated for each of the trials based on fitted parameter estimates

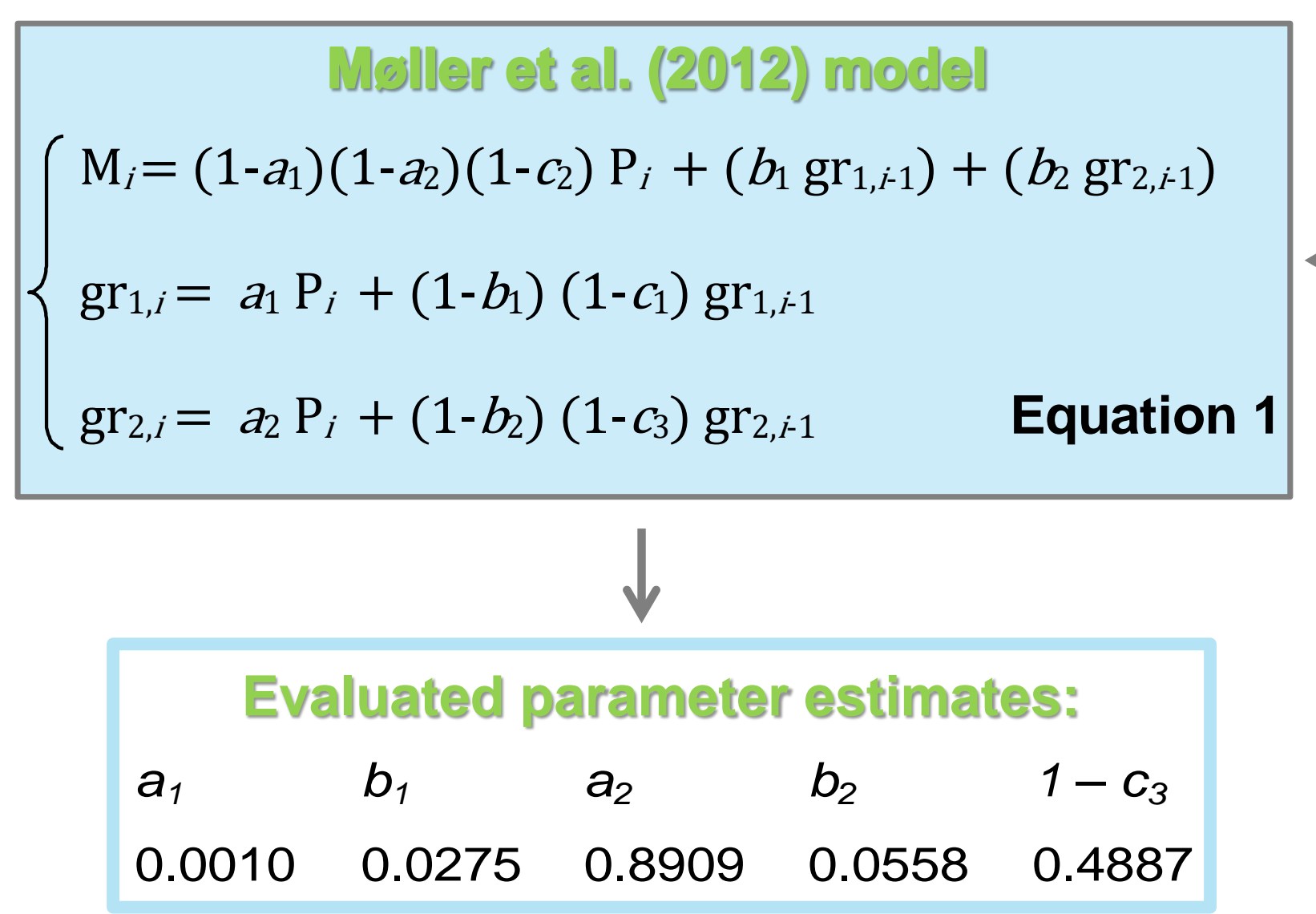

\section{Lessons learned:}

Results indicated that transfer estimates were not applicable for unlike processing

QMRA risk estimates and TTP both revealed that risk attribution from grinding was influenced by:

1) sharpness of grinder knife

2) specific grinder

3) grinding temperature

4) specific pathogen was of minor importance

Bxplaining unglor et al. (2012) model

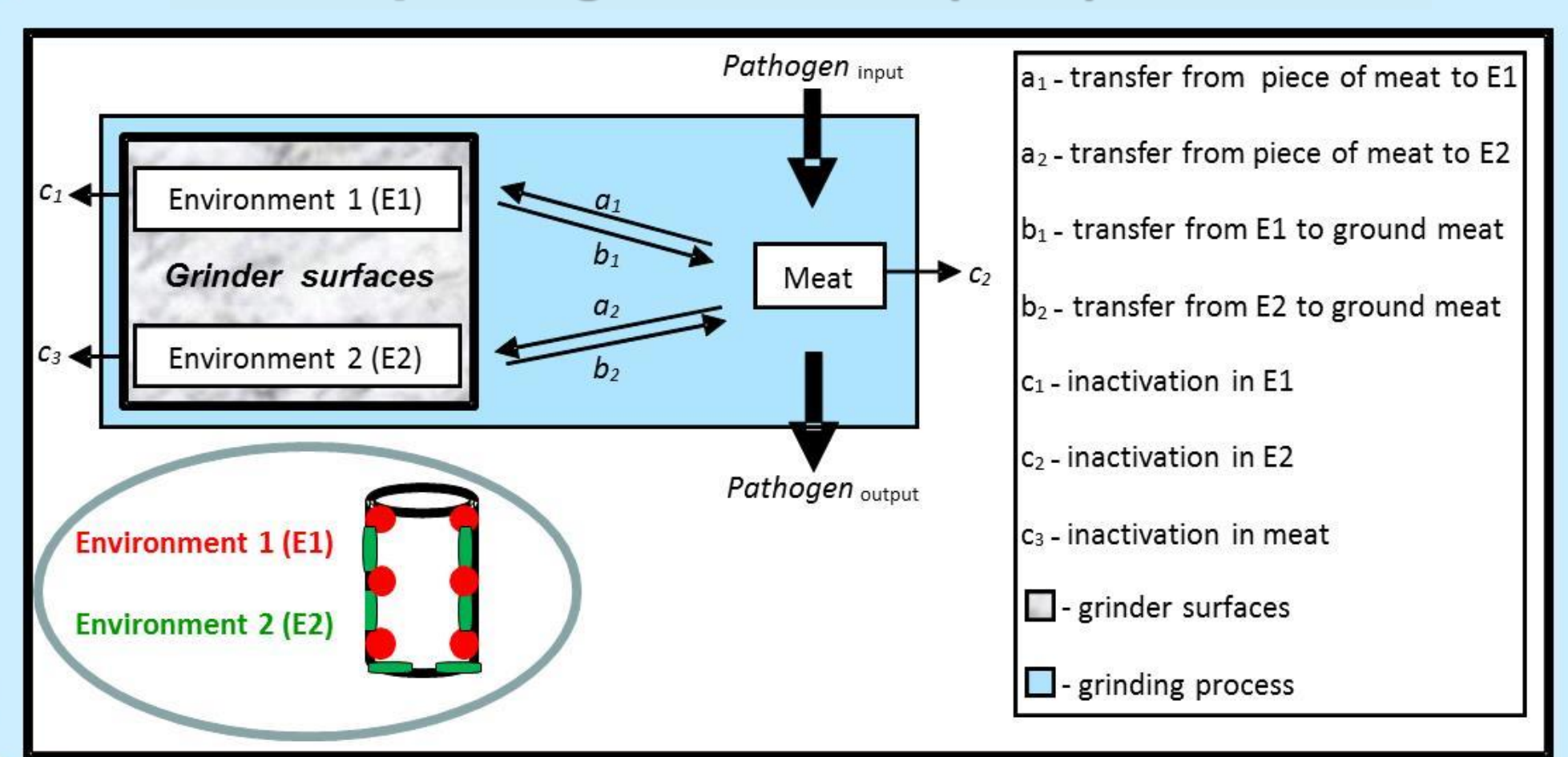

Classification of trials according agreement of results obtained with three different approaches for evaluating performance of the model proposed by Møller et al. (2012) describing the transfer of pathogens during meat grinding in trials with at least 15 pieces of meat.

\begin{tabular}{|c|c|c|c|c|c|c|}
\hline \multirow{2}{*}{$\begin{array}{l}\text { Trial } \\
\text { identification }\end{array}$} & \multirow{2}{*}{$\begin{array}{l}\text { Size of } A S Z^{b} \text { to include } \\
95 \% \text { of the predictions } \\
\text { ( } \pm \text { CFU/portion of meat) }\end{array}$} & \multirow{2}{*}{$\begin{array}{l}\text { Absolute Risk }{ }^{\mathrm{C}} \\
\text { Estimates } \times 10^{-3}\end{array}$} & \multirow[t]{2}{*}{ TTP $\%^{d}$} & \multicolumn{2}{|c|}{ Møller et al. (2012) model } & \multirow{2}{*}{$\begin{array}{c}\text { A positive correlation was found } \\
\text { between QMRA risk estimates } \\
\text { and TTP } \%\end{array}$} \\
\hline & & & & Applicability & $\begin{array}{l}\text { Evaluation approaches } \\
\text { in agreement }\end{array}$ & \\
\hline 1 & 2.0 & 3.02 & 103 & - & 3 & \\
\hline 2 & 2.0 & 2.87 & 101 & & 3 & \\
\hline 3 & 2.0 & 2.94 & 100 & - & 3 & Evalluaten \\
\hline 4 & 0.8 & 1.01 & 21 & + & 3 & Eveluelleu f \\
\hline 5 & 1.4 & 1.56 & 36 & + & 2 & $\triangle P D I I C A R$ \\
\hline 6 & 1.2 & 1.10 & 24 & + & 2 & $158 \%$ of 1 \\
\hline 7 & 1.1 & 0.86 & 16 & + & 2 & \\
\hline 8 & 1.2 & 0.62 & 11 & + & 2 & \\
\hline 9 & 2.0 & 2.21 & 60 & - & 3 & \\
\hline 11 & 1.1 & 1.92 & 51 & - & 3 & Evaluated \\
\hline 12 & 1.4 & 3.04 & 102 & - & 3 & או \\
\hline 13 & 1.2 & 1.44 & 35 & + & 2 & (42\% of trials) \\
\hline 14 & 1.5 & 2.22 & 64 & - & 3 & \\
\hline 15 & 1.1 & 1.54 & 36 & + & 2 & \\
\hline 16 & 1.1 & 2.24 & 60 & - & 3 & \\
\hline 17 & 2.2 & 1.59 & 39 & + & 2 & Nevertheless $\longleftarrow$ \\
\hline 18 & 0.6 & 1.41 & 34 & + & All tr & Is were successfully \\
\hline 19 & 0.6 & 1.14 & 25 & + & des & ibed when fitted to \\
\hline $20^{\mathrm{a}}$ & 0.5 & 0.96 & 20 & + & 3 & equation 1 \\
\hline \multicolumn{7}{|c|}{$\begin{array}{l}{ }^{a} \text { Parameter estimates suggested by Møller et al. (2012) and evaluated in this study were obtained from the fitting of observed } \\
\text { transfer in trial } 20 .\end{array}$} \\
\hline \multicolumn{7}{|c|}{${ }^{\mathrm{b}}$ ASZ - Acceptable Simulation Zone. } \\
\hline \multicolumn{7}{|c|}{$\begin{array}{l}{ }^{\circ} \text { Risk estimates from scenarios testing different sets of transfer parameter estimates, and using the QMRA of Salmonella in meatball } \\
\text { processing model (Møller et al., 2015) at low concentration and prevalence of the pathogen. }\end{array}$} \\
\hline
\end{tabular}
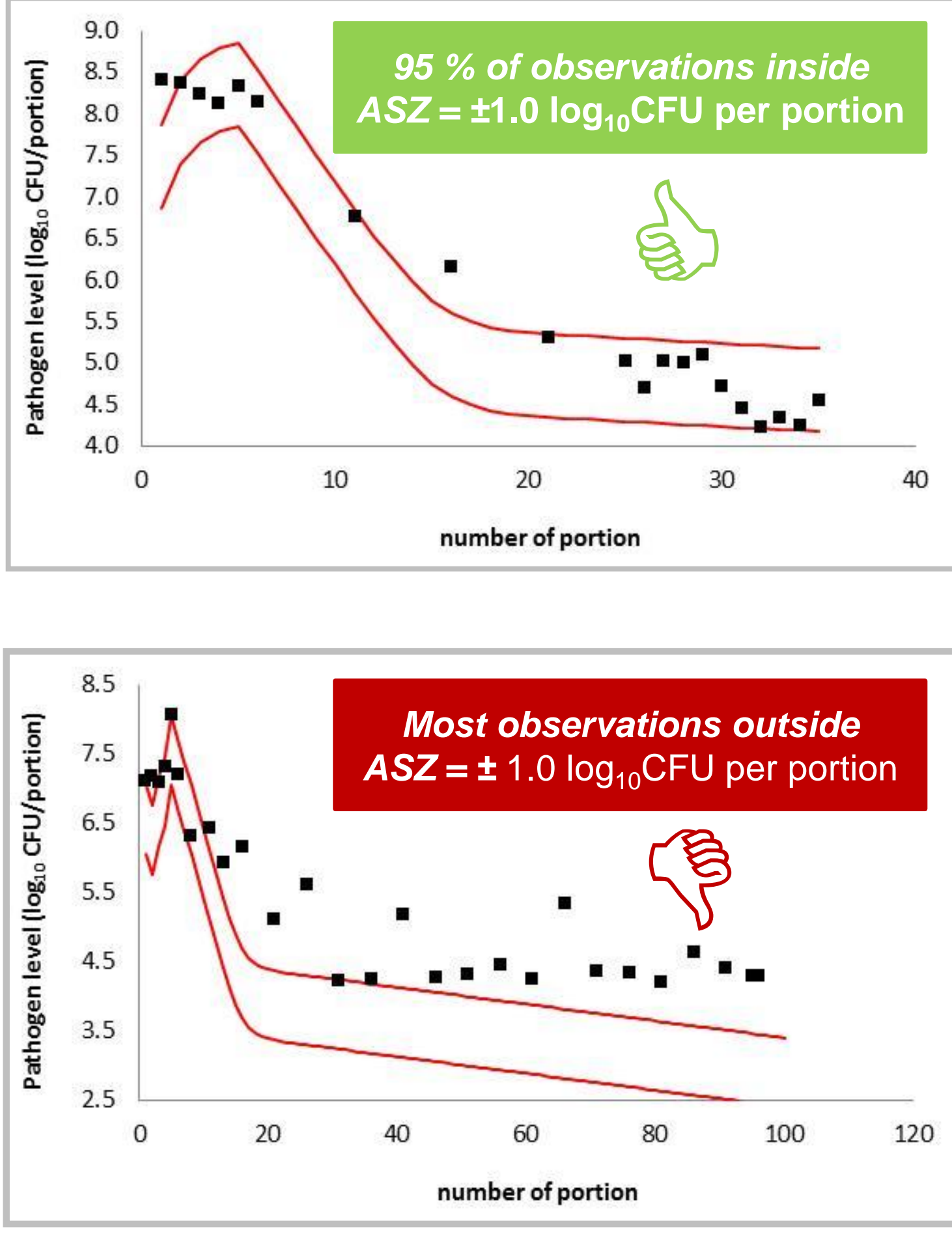

Acknowledgement

The present study was financed by the Danish Council for Strategic Research (DCSR, process 12-1311417) and the State of Săo Paulo Research Foundation (FAPESP, Strategic Research allation 5 (n) State of São Paulo, Brazil and Denmark.

.
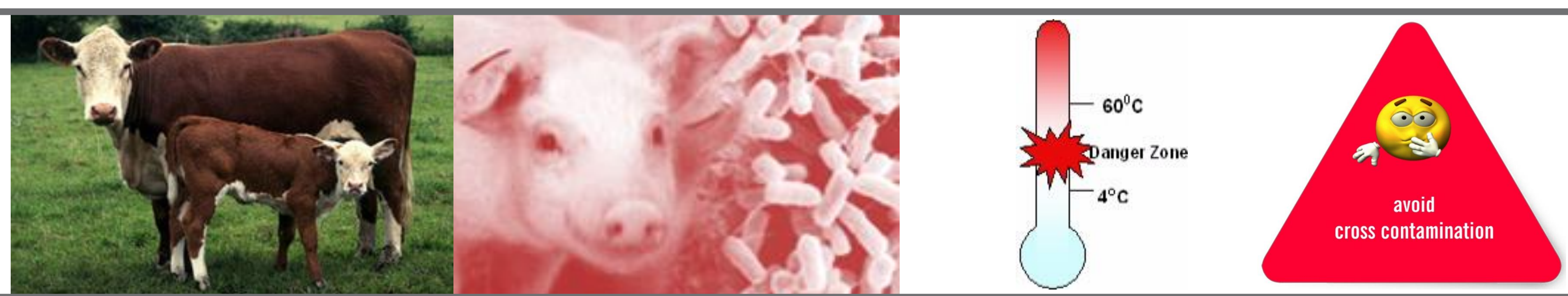